\title{
"Trójka widm w bezokoliczniku". Spektralne koniugacje Witolda Wirpszy
}

Piotr Bogalecki

TEKSTY DRUGIE 2016, NR 2, S. 254-271

DOI: 10.18318/td.2016.2.13

$\mathbf{Z}_{\mathrm{t}}^{\mathbf{n}}$ niknęły widma, został tylko głos i mechanizm" tymi słowami komentował Jerzy Kwiatkowski puentę opublikowanego w 1956 roku poematu Sobie i diabtu, w którym, jak oceniał, za pomocą "szatańskich metamorfoz", "kostropatej melodii” i „mechanicznego rytmu” udało się Witoldowi Wirpszy oddać „mechanizmy” socrealistycznej rzeczywistości'. Diagnoza ta może dawać do myślenia i dziś - chociaż trudno uznać ją za prognozę bezbłędną. O ile bowiem krytyk okazał się niezwykle dalekowzroczny, proponując, by interpretować poezję autora Traktatu sktamanego za pomocą kategorii "głosu i mechanizmu", o tyle w kwestii widm zwiodło go cokolwiek naiwne przekonanie, że „dziś wiele z [...] diabelskich spraw widzimy jasno i możemy o nich mówić"2. Co prawda Wirpsza szybko pożegnał się z mającą wyraziste polityczne konotacje figurą diabła (w ostatecznej ocenie Kwiatkowskiego decydującą zresztą o "nędzy" poematu
Piotr Bogalecki - dr, adiunkt w Katedrze Literatury Porównawczej Uniwersytetu Śląskiego. Autor monografii "Niedorozmowy".Kategoria niezrozumiałości w poezji Krystyny Miłobędzkiej (2011, Nagroda Narodowego Centrum Kultury) oraz Szczęśliwe winy teolingwizmu. Polska poezja po roku 1968 w pespektywie postsekularnej (w druku). Kontakt: pbogalecki@gmail.com

1 J. Kwiatkowski Szyfry. O poezji, "Życie Literackie” 1956 nr 26, s. 5.

2 Tamże. 
i przeistaczającą go w „jeden ogromny zakalec”3), ale to bynajmniej nie jej dalsze przekształcenia miały zadecydować o pojawieniu się nowych widm, które już wkrótce nawiedzać zaczęły jego coraz odważniej eksperymentującą poezję. Odwracając dictum Kwiatkowskiego, można zaryzykować raczej następujące rozumowanie: „został tylko głos i mechanizm” - musiały więc pojawić się widma. Jeżeli bowiem dziś możemy określać Wirpszę mianem poety widmowego par excellence - a odwołując się do rozróżnienia Giorgia Agambena, można uznać go wręcz za „widmo doskonałe” - to nade wszystko z uwagi na sukcesywnie wypracowywane i niemalże mechanicznie wykorzystywane procedury rządzące jego twórczością poetycką. W ujęciu Gilles'a Deleuze'a procedura - podobnie jak nazywane przez niego „formułą” słynne, na poły agramatyczne zdanie I would prefer not to, pochodzące z Bartleby'ego Hermana Melville'a - „wprowadza do wnętrza języka obcą mowę, konfrontuje go z milczeniem, spycha w stronę ciszy, [...] pustoszy język, [...] tworzy próżnię we wnętrzu mowy"5. O ile jednak, jak podkreśla Deleuze, w wypadku Bartleby'ego istotnie spowodowało to „długie milczenie" (zarówno bohatera noweli, jak i jego protoplasty) ${ }^{6}$, o tyle w wypadku Wirpszy raz uruchomioną machinę procedur, anektujących coraz to nowe obszary polszczyzny, zatrzymać mogła

3 Tamże.

4 Zob. G. Agamben O zaletach i niedogodnościach życia wśród widm, w: tegoż Nagość, przeł. K. Żaboklicki, W.A.B., Warszawa 2010, s. 47-52. Stawiając tezę o widmowości Wirpszy, nie sposób nie wspomnieć o fantomowym statusie jego opus magnum: rekomendowany do druku już w 1969 roku "polimorficzny” poemat Faeton długo krążył po Europie w postaci maszynopisu, "obecny w świadomości krytycznej na prawach legendy" (D. Pawelec Wirpsza wielokrotnie, Instytut Mikołowski, Mikołów 2013, s. 91); nie mniej widmowa okazała się też recepcja jego pierwszego, podziemnego i niskonakładowego, wydania z 1988 roku; w końcu zaś nawet w edycji Instytutu Mikołowskiego z lat 2006-2007 przyszło mu egzystować w osobliwie pokawałkowanej i jakby wciąż niefinalnej postaci (jako Faeton i Faeton II). Widmowa może wydawać się też obecność Wirpszy w ostatnich dwóch dekadach, w których - jak twierdzi Pawelec - jawił się on jako „nieobecny wzorzec", który coraz mocniej nawiedza polską poezję, stopniowo przeistaczając się w byt "realnie obecny i żywo oddziałujący" (tamże, s. 95). Do tego można dodać pojawiające się co rusz zaiste fantomowe klisze recepcyjne (w swej monografii skrupulatnie wylicza je Pawelec), a także obecność archiwów (zdaniem Derridy zawsze posiadających widmową strukturę), z których przynajmniej od kilku lat wyłaniają się kolejne teksty Wirpszy (ostatnio Listyz Oflagu, oprac. D. Pawelec, Zaułek Wydawniczy Pomyłka, Szczecin 2015, a także "Salut Henri! Don Witoldo!". Witold Wirpsza - Heinrich Kunstmann: listy 1960-1983, wstęp, przekł. i oprac. D. Cygan, M. Zybura, Universitas, Kraków 2015).

5 G. Deleuze Bartleby albo formuła, przeł. G. Jankowicz, w: H. Melville Kopista Bartleby. Historia z Wall Street, przeł. A. Szostkiewicz, Sic!, Warszawa 2009, s. 72-73.

6 Tamże, s. 72. 
tylko śmierć. Nawet ta jednak, na zawsze dławiąc głos zmarłego w 1985 roku autora, nie odebrała nam możliwości obcowania z pogłosem jego tekstów, tropienia w nich poetyckich mechanizmów, a w końcu doświadczania we własnej mowie skutków uruchomionych przez niego procedur. Te ostatnie nie mogły mieć u pisarza tak proteuszowego jak Wirpsza jednorodnego charakteru, bez wątpienia jednak stale eksplorowały problematykę językowego poznania, co sprawiło, że najważniejszym punktem odniesienia rychło stał się dla nich język nauki. Intuicje badaczy poezji Wirpszy pozostają zgodne z klasycznym rozpoznaniem Edwarda Balcerzana, zgodnie z którym została ona pomyślana jako „system precyzyjnych i ogólnych pojęć: terytorium zwycięstwa struktur ekspansywnych, bogatych w abstrakta, nad typami recesywnymi"7. Rzecz jasna jednak, jak zauważa Joanna Grądziel-Wójcik, w twórczości poetyckiej „możliwa jest jedynie gra z językiem naukowym i formą wyjaśniającą, przejmowanie ich zewnętrznych, stylistycznych cech, nie zaś funkcji"8. $\mathrm{Z}$ pewnością to właśnie z taką aktywnością mamy do czynienia w tekstach Wirpszy - autora Gry znaczeń i tłumacza Homo ludens Huizingi - w których wywiedziona z tradycji kantowsko-schillerowskiej kategoria zabawy wydaje się pełnić rolę kluczową9. Zastrzeżenie to nie oznacza bynajmniej, że błędne musiałyby być rozpoznania upatrujące w działaniach Wirpszy istnienia jakiegoś projektu (jak teza Piotra Michałowskiego, zgodnie z którą „zatarcie się różnic pomiędzy językiem poezji a językiem nauki” stanowi „zapowiedź jakiejś post-nauki"10), a tyle tylko, że mają one wiele wspólnego z Agambenowskimi profanacjami. Te ostatnie wszakże - według włoskiego filozofa „nie dotyczące [...] tylko obszaru religijnego” - podobne są do zabawy, bezceremonialnie „rozbrajającej” rzeczy należące do „dziedzin zwyczajowo

7 E. Balcerzan Poezja polska w latach 1939-1965, cz. II: Ideologie artystyczne, WSiP, Warszawa 1988, S. 92-93.

8 J. Grądziel-Wójcik Poezja jako teoria poezji. Na przykładzie twórczości Witolda Wirpszy, Wydawnictwo Naukowe UAM, Poznań 2001, s. 49.

9 Nieprzypadkowo zabawa i jej pole semantyczne (gra, rozrywka, taniec, zabawki itd.) stały się tematem wielu tekstów poetyckich Wirpszy. W kontekście tematu niniejszego artykułu największe znaczenie wydaje się mieć poemat Wykorzenienie, w którym z zabawy wywiedziona została autorska wykładnia "uduchowienia" (więcej piszę o tym w artykule "Naczynia znaków pustych". "Wykorzenienie" Witolda Wirpszy jako poemat postsekularny, "FA-art” $2013 \mathrm{nr}$ 1-2, S. 25-41).

10 P. Michałowski Witold Wirpsza: między alchemiq a akademiq̨ " Poznańskie Studia Polonistyczne” (Seria Literacka) 2006 z. XIII, s. 57. 
uznawanych za poważne"11. Agamben przyznałby z pewnością, że tym, co łączy poetyckie „przedrzeźnianie” naukowych procedur „z profanacją świętości, jest przejście od religio postrzeganej jako fałszywa i opresyjna, do niedbałości pojmowanej jako vera religio. Ta niedbałość nie oznacza braku zaangażowania (dzieci są często całkowicie pochłonięte zabawą), ale nowe zastosowanie"12. W tym świetle mechanizmy widmowego nawiedzania języka nauki - czy też, jak powiedziałby pewnie sam poeta, jego „pisarskiego pożytkowania” - nie byłyby ani wyłącznie poważne, ani jedynie prześmiewcze, ale umożliwiałyby nowe, profanacyjne zastosowania, w istocie modyfikujące jego dotychczasowe funkcje. Skoro zaś lingwistyczne procedury Wirpszy faktycznie miałyby mieć profanacyjny, nie zaś jedynie przemieszczeniowy ${ }^{\mathbf{1 3}}$, charakter, można przypuszczać, że najciekawsze efekty uzyska on wtedy, gdy zwróci się do tego języka, który powołał do życia samą możliwość profanacji. Zainteresowanie autora Traktatu skłamanego dyskursem teologiczno-religijnym może jawić się zatem jako nieprzypadkowe i konsekwentne ${ }^{14}$.

\section{Pytanie o pytanie (na które odpowiedzią jest widmo)}

W opublikowanym dokładnie trzy dekady po śmierci pisarza wierszu Zgryzota idalekie światto ${ }^{15}$ działanie jego poetyckiej procedury dotyka sposobu zadawa-

11 G. Agamben Pochwała profanacji, w: tegoż Profanacje, przeł. M. Kwaterko, PIW, Warszawa 2006, s. 96-97.

12 Tamże, s. 97.

13 Dzieje się tak w przeciwstawionej profanowaniu sekularyzacji, według Agambena będącej "rodzajem stłumienia, który nie narusza żadnych sił, lecz jedynie prowadzi do ich translokacji" (G. Agamben Pochwała profanacji..., s. 98).

Podobnie rzecz ma się z odczytywaniem jego poezji w odniesieniu do myśli Agambena, nie przez przypadek przecież zainteresowanego (literackimi ex definitione) "wyjątkowymi gestami językowymi", które Paweł Mościcki proponuje "dla znalezienia wspólnego mianownika - nazwać formułami" (P. Mościcki Idea potencjalności. Możliwość filozofii według Giorgio Agambena, Wydawnictwo IBL PAN, Warszawa 2012, s. 341). To, co Mościcki pisze o Agambenie, można, jak sądzę, z niewielką tylko modyfikacją odnieść do mechanizmów poetyckich Wirpszy, które - dla znalezienia wspólnego mianownika (a zatem z pominięciem psychoanalitycznych konotacji) nazywam tu procedurami: także i one służyłyby „do zaznaczania pewnej szczególnej praktyki mówienia i poznawania, otwartego na niewiedzę, umieszczającej w samym środku dyskursywnych rozważań pewien rodzaj gagu, który pozwala językowi tańczyć wraz z myślą" (tamże, s. 342). Na temat związków zabawy, profanacji i mesjanizmu zob. tamże, s. 365-380.

15 W tomie Czq̨stkowa próba o człowieku i inne wiersze, Instytut Mikołowski, Mikołów 2005 (dalej jako $(P)$. 
nia pytań - jakby nie patrzeć, naszej podstawowej aktywności poznawczej, stanowiącej niezbywalny element dyskursu naukowego. UWirpszy wszakże zapytywanie nie przypomina bynajmniej Heideggerowskiej „pobożności myślenia"; nasuwa na myśl raczej mityczny pojedynek z lernejską hydrą - z tą różnicą, że zamiast odrastających głów w tekście Zgryzoty co rusz pojawiają się nowe zjawy. Już w pierwszych wersach z jednej wysuniętej sugestii natychmiast wyłania się - niejako w zastępstwie odpowiedzi - „trójka widm”, aby przy akompaniamencie „syków” i „dudnienia” zmusić pytającego do daremnej ucieczki w egzorcyzm. Mając przed oczyma tekst wiersza, a w pamięci sąd Grądziel-Wójcik o „akrybii interpunkcyjnej” Wirpszy ${ }^{16}$, można łatwo zauważyć znaczącą osobliwość: oto żadne z siedmiu „pytań”, unoszących filozoficzną problematykę tekstu, nie zawiera pytajnika; są one konsekwentnie wieńczone kropkami, a co za tym idzie pozbawione intonacji wznoszącej, sygnalizującej intencję podmiotu mówiącego. Zapis ów nie tylko utrudnia recytację, ale bez wątpienia - z uwagi na swą powtarzalność - wpływa na semantykę tekstu. Czas najwyższy przywołać wiersz w całości:

Czy należy wyzbyć się wiary,

Aby zniweczyć zgryzotę. Wyłania się

Trójka widm w bezokoliczniku:

Wierzyć, wiedzieć, widzieć. Szeleszczą

Zapisem papiery traktatów. Czy można

(Należy) tak widzieć, aby wierzyć; tak

Wierzyć, aby widzieć. Dudnią

Oprawne księgi rozpraw historycznych.

Czy należy (można) tak wiedzieć, aby

Widzieć. Syczy służalcze krasomówstwo.

Czy należy (można) tak wiedzieć, aby wierzyć.

Odejdź ode mnie, widmo zgmatwane,

Pochylone nad piachem, umywające

W piachu dłonie, ociekające ziarnistym

Potem: sina chmuro rzemiennego zwierzęcia.

Wszystko, co przenosi, jęczy albo stęka:

W motorach spalinowych powietrza, ziemi

I wody, w koleinach i na podkładach,

16 J. Grądziel-Wójcik Poezja jako teoria..., s. 27. 
A także, kiedy brzęczenie dokonuje transportu

Słów w polu elektromagnetycznym; a także,

Kiedy kosmonauta uruchamia silnik pomocniczy.

Każde drganie daje się przełożyć na

Mowę stękania i jęczenia. Ale to jeszcze

Nie zgryzota: jęczenie, stękanie, transport,

Przekład; to technologia, jeszcze nie mnogość

Widm. Obojętne, czy się tego pozbywamy, czy nie.

Jeśli ktoś wierzy, niech się i pozbywa wiary.

Czy do wiary należy ufność. Jeśli ktoś nie

Wierzy, i jakże może pozbyć się zgryzoty. Zgryzota

Przynależy do wiary i niewiary zarówno.

Czy do niewiary przywiązana jest nieufność.

Widma ciężkich zwierząt wznoszą kłęby

Sinego piachu i ruchu bydlęcego.

Uniesienia umywają swoje ludzkie dłonie.

Trudna ziarnina obrasta sploty sumienności.

Sumienność mimo pokrewieństwa etymo-

Logicznego nie ma nic do sumienia.

Sumienie: wielkie widmo zgryzoty, wielki

Rzemień zgryzoty, wielki przewóz zgryzoty.

Dalekie światła zgryzoty, moc i

Przenikliwość dalekich świateł. (CP 90-91)

Pytanie pozbawione pytajnika nie do końca jest pytaniem. Istnieje w specyficznie nieokreślonej „niepytajnej” postaci. Owa widmowa postać - postać widma - wywołuje niepokój i otwiera spektrum interpretacji. Być może parodiuje ona język nauki, możliwe też jednak, że nawiązuje do zapisu zdań w mowie zależnej, niejako upubliczniając tym samym dyskurs (jak gdyby Wirpsza mówił: „Zapytajmy, czy należy wyzbyć się wiary, aby zniweczyć zgryzotę"), tudzież odsuwając moment podmiotowego zaangażowania (odpowiednio: „Pytanie, czy należy wyzbyć się wiary, aby zniweczyć zgryzotę”). Wreszcie może ona jedynie markować ruch myśli - ale i w tym wypadku należy zapytać, czy dzieje się to z braku wiary w możliwość udzielenia odpowiedzi, czy raczej z nadmiaru wiedzy, jak w wypadku pytania retorycznego. Odchodząc od utrwalonego znaczenia tego ostatniego zabiegu, można powiedzieć, że 
wszystkie pytania Wirpszy są pytaniami retorycznymi: nie idzie w nich bynajmniej o udzielenie takiej czy innej odpowiedzi (stąd brak pytajnika), natomiast bez wątpienia odsłaniają one de Manowską retoryczność języka" ${ }^{17}$. Odsłonięcie to określi Agamben mianem jedynego dostępnego nam dziś „objawienia”, porównując je przy tym do „kopernikańskiego przewrotu” i zaznaczając, że jego treścią jest „mowa całkowicie opuszczona przez Boga. Człowiek [...] został wrzucony w język, nie mając głosu ani boskiego słowa, które gwarantowałoby mu możliwość ucieczki od nieskończonej gry znaczących zdań"18. Oto kolejny możliwy powód, dla którego poezja Wirpszy - usilnie starająca się odpowiedzieć na owo odziedziczone po nihilizmie objawienie - nawet kiedy pyta, robi to bez pytania. Skoro, inaczej niż w tradycji ontoteologicznej, język cechuje się „absolutną bezimiennością", skoro „nie ma w nim nazwy dla nazwy”, skoro po raz pierwszy postrzegamy go jako „w pełni wyjawiony" ${ }^{\prime \prime}$ - to zamiast pytać z jego pomocą o wiarę czy wiedzę, należałoby spróbować zobaczyć sam język, dotrzeć do "wizji sa mego języka”, a zatem, jak powiada Agamben, oddać się „teorii idei"20. Zanim jednak stanie się to możliwe, trzeba najpierw - niczym Wittgensteinowska mucha uwięziona w szklance - doświadczyć ograniczeń języka, ,jego k r e s u"21. Jak można sądzić, jednym (choć nie jedynym) z celów poezji Wirpszy jest wywołanie takiego doświadczenia; w Zgryzocie i dalekim świetle dobrze służy temu omawiana procedura.

Odnosząc się do przywołanego opowiadania Melville’a, Deleuze zwróci uwagę, że formuła „zawiesza referencjalną funkcję języka, zgodnie z absolutnym powołaniem Bartleby'ego, żeby stać się człowiekiem bez refe r e n c j i, kimś, kto zjawia się znienacka, a potem znika bez śladu"22 . Komentujący ten fragment Agamben dopowie natomiast, że wyrażenie I would prefer not to „dobitnie wyraża stan zawieszenia między twierdzeniem a przeczeniem, akceptacją a odmową, uznaniem a odrzuceniem"23. W podobny sposób

17 Zob. np. P. de Man Alegorie czytania. Język figuralny w Rousseau, Nietzschego, Rilkego i Prousta, przeł. A. Przybysławski, Universitas, Kraków 2004. G. Agamben Idea języka, przeł. A. Wasilewska, "Literatura na Świecie” 2011 nr 5-6, s. 375.

19

20

Tamże, s. 375-376.

Tamże, s. 376.

Tamże, s. 377.

G. Deleuze Bartleby albo formuła..., s. 74 .

G. Agamben Bartleby, czyli o przypadkowości, przeł. S. Królak, w: H. Melville Kopista Bartleby..., S. 129. 
zawiesza pytania - ale i problematykę, jakiej one dotyczą - procedura Wirpszy. Nie idzie w niej bynajmniej o odmowę odpowiedzi, ani nawet nie o krytykę samych pytań jako „źle postawionych”, ale o ich przeniesienie w nierozróżnialną, widmową „sferę, w której niepodobna odróżnić «tak» od «nie», tego ku czemu wola się skłania, od tego, czemu się sprzeciwia"24. Biorąc pod uwagę to, że tematykę wiersza (z kluczowym dla niego napięciem między potencjalnie zbawczą wiarą, potencjalnie wyzwalającą wiedzą, a stale ciążącą nam „zgryzotą") należałoby określić jako teologiczno-religijną - ale i pamiętając, że w dyskursie tym obowiązująca zasada "Niech wasza mowa będzie: tak, tak, nie, nie” (Mt 5,37) - powiedzieć można, że niepróbujący „odróżniać «tak» od «nie»" tekst Wirpszy dobrze wpisuje się w model poszukiwań postsekularnych, stale problematyzujących relacje między wiarą i wiedzą (by wymienić tu tylko Wierzyć i wiedzieć Habermasa, Wiarę i wiedzę Derridy czy Credere di credere Vattimo). Dopowiedzieć należałoby też, że chociaż analogiczna procedura znalazła zastosowanie w kilku innych tekstach tak chętnie „eksperymentującego z interpunkcją"25 poety, to w wypadku Zgryzoty i dalekiego światła jej zastosowanie wydaje się o tyle trafne, że wiersz ten tematyzuje samą utratę przez język komunikowalności. Znaczące jest, że za zdarzenie to odpowiadają w nim nie tyle nawet widma, ile sama widmowość języka - co pozwala uznać go za jeden z najbardziej oryginalnych, przenikliwie „widmowych" tekstów w polskiej literaturze.

\section{W stronę gramatyki widma (bez okoliczności)}

Mimo że wielu autorów poświęciło swoje studia badaniu widmowej „anatomii”, odpowiedź na pytanie, „z czego powstało widmo"26, może być tylko jedna. W cytowanym już eseju $O$ zaletach i niedogodnościach życia wśród widm z godną podziwu lakonicznością udziela jej Agamben („Ze znaków”27), ale również i Wirpsza, mówiąc o „trójce widm w bezokoliczniku”, wydaje się trafiać w sedno. W formule tej widmo staje przed nami w całej prawdzie - nagiej prawdzie, jak moglibyśmy powiedzieć za Onufrym Kopczyńskim, piszącym

\footnotetext{
24 Tamże, s. 128. 
w swojej Teoryi czasowań: „Jak już Imię malujące rzeczy, tak Słowo, malując Sąd o rzeczach, nie są gołe, ale z tysiącznemi złączone względami, czyli okolicznościami: musi przeto Słowo malować nietylko gołe wyobrażenie Sądu, ale też okoliczności tegoż Sądu"28. Jeżeli w żywej mowie Słowo (u Kopczyńskiego w znaczeniu: 'czasownik') nigdy nie pojawia się "gołe”, to pozbawiony odzienia bezokolicznik nie może nie stanowić wobec niej zastanawiającego ekscesu. Obwieszczając nadejście „widm w bezokoliczniku”, rozrywa Wirpsza związek między tym, co językowe, a tym, co „okolicznościowe” - „względne”, przyziemne, przygodne. Z formuły autora Przerobu wyłania się możliwa definicja widma, stanowiąca zarazem określenie jego działania: widmo obraca żywą mowę w pył, przeistaczając ją w zbiór martwych elementów uszeregowanych w karny szyk słownikowej szpalty. Pod nieobecnym spojrzeniem widma (o którym, w odniesieniu do sceny ze zjawą Ojca Hamleta, tak wymownie pisał Derrida ${ }^{29}$ ) owo niewiarygodnie "giętkie" narzędzie komunikacyjne, pozwalające wyrażać całą gamę rozmaitych odcieni emocjonalno-znaczeniowych - zastyga w abstrakt: nieludzki i przeraźliwie łatwo poddający się leksykograficznemu uporządkowaniu. W istocie to w słowniku najłatwiej odnaleźć bezokolicznik; warto pamiętać jednak, że równie charakterystyczna jest jego pozycja gramatyczna. Niezależnie bowiem od tego, że „znajduje [on] wielorakie zastosowanie w konstrukcjach składniowych"30 , nie jest bezokolicznik „ani formą koniugacyjną, ani deklinacyjną"31, lecz stanowi - jak ujęła to Barbara Bartnicka - „formę pozostającą pozą fleksją”, tudzież - jak wolał Jan Tokarski - przykład struktury afleksyjnej ${ }^{32}$. Już Antoni Małecki przekonywał, że wyrażając „samo tylko znaczenie i niejako treść słowa, bez wszelkich [...] okoliczności”, staje bezokolicznik ,jakby na pograniczu koniugacji i deklinacji, czyli na pograniczu słowa i rzeczownego imienia"33. To owa frapująca osobność bezokolicznika odpowiedzialna jest z pewnością za rozpowszechnioną niegdyś fantazję

28 O. Kopczyński Grammatyka języka polskiego. Dzieło pozgonne, [brak wydawcy], Warszawa 1817, S. 99.

29 Zob. J. Derrida Specters of Marx. The State of the Debt, the Work of Mourning and the New International, transl. P. Kamuf, Routledge, New York-London 2006, s. 125-126.

30 B. Bartnicka Funkcje semantyczno-składniowe bezokolicznika we współczesnej polszczyźnie, Zakład Narodowy im. Ossolińskich, Wrocław 1982, s. 11. Tamże, s. 10. Zob. J. Tokarski Czasowniki polskie, Wydawnictwo S. Arcta, Warszawa 1951, s. 31.

33 A. Małecki Gramatyka języka polskiego mniejsza dla użytku gimnazjów i szkół realnych ułożona, [b.d.w.], Lwów 1866, s. 77; cyt. za: B. Bartnicka Funkcje..., s. 7. 
genetyczną; m.in. Rousseau był zdania, że w początkowej fazie rozwoju języka był „bezokolicznik [...] w czasie teraźniejszym - jedyną formą czasownika”34. W polemikach z tego typu stanowiskami zwracano uwagę, że sprzeciwia się im „sam sposób pojmowania ludzkiego; bo człowiek zawsze od łatwiejszych do trudniejszych, przez znane do nieznanych rzeczy przechodzi"35. W efekcie bezokolicznik zaczął być postrzegany jako forma najmniej „naturalna”, a najbardziej wyspecjalizowana, najtrudniejsza.

Na tle przypomnianych tu rozróżnień, intuicja Wirpszy - ostatecznie niebędąca wszakże intuicją językoznawcy, a poety - jawi się jako tyleż prosta, co nieuchronnie metaliteracka. Skoro w systemie koniugacyjnym za ekwiwalent widmowości można uznać sytuujący się na jego pograniczu bezokolicznik w największym stopniu wydestylowaną, rzeczownikową, oderwaną od konkretu życia formę czasownika - to na kontakt z przychodzącymi „w bezokoliczniku" widmami wystawiamy się wówczas, gdy podejmujemy świadomy namysł nad językiem jako systemem. Jeżeli na ogół, zanurzeni w nieuchronnym automatyzmie mówienia, nie uświadamiamy sobie, że żyjemy pośród widm, to z pewnością wydajemy się na ich pastwę, stając się językoznawcami, badaczami języka, w końcu zaś poetami - jak również, na innym już poziomie, odbiorcami poezji, doświadczającymi dezautomatyzującego oddziaływania języka poetyckiego i podejmującymi nad nim namysł. W takim ujęciu za jedną z uprzywilejowanych sposobów eksploatowania przyrodzonej językowi widmowości należy uznać poezję lingwistyczną (zwłaszcza w tej jej odmianie, jaką Agnieszka Kluba określa mianem „systemowej”36) - jeżeli tylko nazwy tej nie będziemy traktować wyłącznie jako historycznoliterackiej etykiety, lecz (niezależnie już od zauważonej także przez Wirpszę tautologiczności tego terminu), spojrzymy na nią w pewnym sensie dosłownie, jako na określenie jednego z głównych kierunków rozwoju poezji nowoczesnej: samoświadomego i na różne sposoby generującego zróżnicowane „momenty lingwistyczne”, w których „wiersze poddają refleksji lub omawiają swoje własne medium”37.

34 J.-J. Rousseau Rozprawa o nierówności, s. 163; cyt. za: tegoż Szkic o pochodzeniu języków, przeł. B. Banasiak, Aureus, Kraków 2001, s. 91.

35 J. Muczkowski Gramatyka języka polskiego, Księgarnia J.A. Munka, Poznań 1825, s. 90; cyt. za: B. Bartnicka Funkcje..., s. 5. Zob. A. Kluba Poetyki lingwistyczne, „Przestrzenie Teorii” 2005 nr 1 (5), s. 100.

37 J. Hillis Miller The Linguistic Moment. From Wordsworth to Stevens, Princeton University Press, Princeton 1985, s. XIV. Zob. też T. Cieślak-Sokołowski Moment lingwistyczny. O wczesnym pisarstwie Ryszarda Krynickiego i Stanisława Barańczaka, Universitas, Kraków 2011, s. 63. 
W analizowanym wierszu ,trójka widm w bezokoliczniku” dotyczy wszakże - od czego nie sposób abstrahować w interpretacji - konkretnych trzech leksemów. „Wierzyć, wiedzieć, widzieć” to ciąg czasowników psychologicznych, których użycie, jak notował Wittgenstein w Kartkach, jest zawsze „zagmatwane. I nie należy oczekiwać niczego innego. [...] Ich zastosowanie nie jest takie jasne i nie tak łatwo je przejrzeć, jak np. zastosowanie słów z dziedziny mechaniki" ${ }^{\prime 3}$. W trzech kolejnych paragrafach zauważał filozof, że tylko okoliczności (Umstände) użycia tego typu czasowników pozwalają poradzić sobie z ich skomplikowaniem ${ }^{39}$. Wirpsza tymczasem, pozbawiając właśnie swoje rozważania o wierze, wiedzy i widzeniu zakorzenienia w takich czy innych okolicznościach (choćby ich istnienie miało być zaledwie zaznaczone gramatycznie, co umożliwiłoby już odwołanie się do konwencji wyznania czy prośby, podstawowych przecież dla tradycyjnych odmian liryki religijnej), uparcie sytuuje się w kondycji „zgmatwania”. Decyzja ta może jawić się nam tyleż jako frapująca, co przeciwskuteczna, a jej paradoksalność dobrze wydaje się ilustrować wers: „Jeśli ktoś wierzy, niech się i pozbywa wiary”. Wittgenstein podkreślał, iż czasowników psychologicznych (m.in. tych, które wybrał Wirpsza) nie sposób „zweryfikować przez obserwację"40, nieuchronnie kierują one zatem myśl ku aktom wiary religijnej; kwestię tę postawił filozof z całą ostrością w ostatnim paragrafie Kartek: „«Boga nie możesz usłyszeć, gdy rozmawia z innym człowiekiem, lecz tylko wtedy, gdy zwraca się do ciebie» Jest to uwaga gramatyczna"41. O ile - jak na podstawie Wittgensteinowskich Wykładów o wierze referuje Józef Bremer - „Ja jako osoba stoję za moimi przekonaniami (ja wierzę)", o tyle „dziwilibyśmy się jednak zdaniu typu: «teraz słyszę Boga rozmawiającego z nim». Coś takiego możemy powiedzieć tylko co do przeszłości, na przykład: «wtedy Bóg rozmawiał z Mojżeszem»"42. Lub też - dopowiedzmy, skoro i tak musi chodzić o przyjęcie czegoś na wiarę - co do przyszłości, na przykład: „I będą oglądać jego oblicze” (Ap 22,4).

Albo przeszłość, albo przyszłość, nigdy teraźniejszość: oto znaleźliśmy się we władzy Aiona - czasu skrupulatnie przeciwstawianego przez

38 L. Wittgenstein Kartki, przeł. S. Lisiecka, KR, Warszawa 1999, s. 34 [fragm. nr 113].

39 Zob. tamże [fragm. nr 114-116].

40 Tamże, s. 111 [fragm. nr 472].

41 Tamże, s. 160 [fragm. nr 717].

42 J. Bremer Ludwig Wittgenstein a religia. Wprowadzenie, WAM, Kraków 2000, s. 85. 
Deleuze'a „pragnącemu śmierci”³ Chronosowi (w tym kontekście byłoby warto porównać Aiona z Pawłowym Kairosem ${ }^{44}$ ). Podczas gdy „wedle Chronosa w czasie istnieje wyłącznie teraz [...] cały czas wypełnia jedynie teraźniejszość, a przeszłość i przyszłość stanowią dwa wymiary zależne od teraźniejszości”, to w „porządku Aiona jedynie przeszłość i przyszłość utrzymują się i trwają w czasie [...], zbierając na powierzchni bezcielesne wydarzenia jako efekty" ${ }^{15}$. Przynajmniej dwie intuicje z Logiki sensu mogą mieć znaczenie w dalszej interpretacji tekstu Wirpszy. Po pierwsze, to Aion jako „świat bezcielesnych skutków, czyli efektów powierzchni, umożliwia mowę"; obecne w nim "czyste wydarzenia stanowią podstawę mowy, ponieważ oczekują

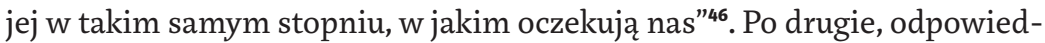
nikiem Aionu nie przez przypadek jest dla francuskiego filozofa „wieczny, zawsze neutralny Bezokolicznik [...], bezcielesny i nieograniczony, niczym pusta forma czasu, niezależna od wszelkiej materii" ${ }^{47}$. W stoickiej „,koniugacji wydarzeń", która stała się podstawą rozumowania Deleuze'a, to „czasownik w formie bezokolicznika wyraża wydarzenie mowy, mowy, która sama jest jedynym wydarzeniem, która stapia się oto z tym, co czynią ją możliwą"48.

\section{Abyś nas odtąd nawiedzał (więcej życia)}

Z punktu widzenia Chronosa „bezokolicznikowy” wiersz o wierze Witolda Wirpszy może jawić się jako pusty, skutecznie wydrążony z miąższu doświadczenia, sytuujący się w wiecznie nieobecnym saeculum. Jego egzystencjalną neutralność, stawiającą go po stronie pewnego uniwersalizmu, moglibyśmy uznać za teologiczną wyłącznie z zastrzeżeniem, że musiałby on reprezentować jakiś rodzaj na poły gnostyckiej, heroicznej teologii „zgryzoty”, w której nienazwany Bóg nie objawiałby się w słowie, ale jawiłby się co najwyżej jako „dalekie światła” (to im w puencie wiersza przypisane zostaną wszakże

G. Deleuze Logika sensu, przeł. G. Wilczyński, PWN, Warszawa 2010, s. 224.

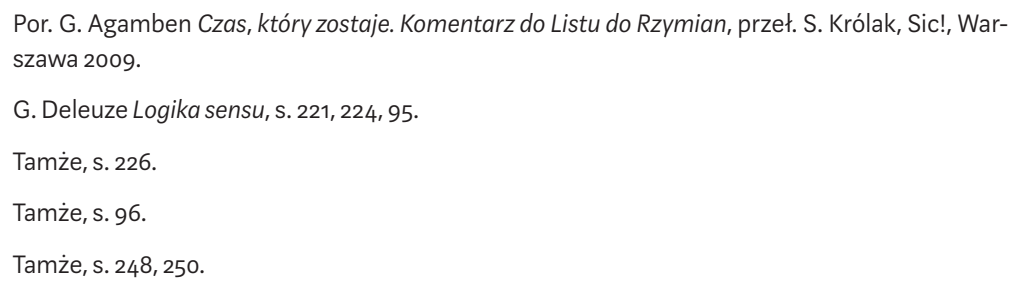


atrybuty istoty boskiej: „Moc i / Przenikliwość dalekich świateł”) ${ }^{49}$. Wydaje się jednak, że bardziej odpowiedzialną odpowiedzią na tekst Wirpszy byłoby przywołanie w tym miejscu „słabej teologii” Johna D. Caputo, który w pochodzącym z 2007 roku artykule Widmowa hermeneutyka nie zawahał się zaryzykować postsekularnej reinterpretacji myśli Deleuze'a, przede wszystkim zaś jego - opartej właśnie na pojęciu Aiona - filozofii wydarzenia ${ }^{50}$. Caputo doskonale zdaje sobie sprawę, że francuski filozof „w Logice sensu, miał o teologii do powiedzenia tylko najgorsze rzeczy", mimo to jednak, inspirując się widmontologią Derridy, rozważa możliwość interpretacji Deleuze'ańskich wydarzeń jako „widmowych”, „zwracających się ku Bogu” i „mesjanistycznych”, przekonując: „A zatem trzeba obrócić swoją twarz ku przyszłości i zostać nawiedzonym przez możliwości zawarte $\mathrm{w}$ wydarzeniach [...] - obiecujące nowe życie, nowe bycie, nowe stworzenie" ${ }^{\text {51 }}$. Staje się to, jego zdaniem, możliwe, gdyż we współczesnej, postsekularnej z ducha, myśli teologicznej „umiejscowienie Boga lub boskości Boga przesuwa się do tego, co się wydarza, od ukonstytuowanych słów i rzeczy w stronę wydarzeń"52. Jeżeli przyjmie się tok rozumowania Caputo, będzie można powiedzieć, że skoro teologia stara się dziś opisać sposoby, w jakie wydarzenie (niczym widmo) „nawiedza” mowę̧, ta ostatnia zaś, jak wiemy od Delueze'a, możliwa jest dzięki (widmowej z ducha) bezokolicznikowej obecności Aiona - to najważniejszym celem postsekularnej poezji Wirpszy byłoby przedstawienie i odegranie prawdy o języku

49 Ponadto, jeśliby sięgnąć do Il sacramento del linguaggio Agambena, gdzie dowodzi się, że „każdy dyskurs religijny opiera się na strukturze przysięgi, w której imię Boga oznacza jednocześnie »czyste i nagie istnienie « oraz stan języka, w którym przylega on do rzeczy, a mówiący podmiot bierze za to powiązanie odpowiedzialność" (P. Mościcki ldea potencjalności..., s. 310) - to „bezokolicznikowy" tekst Wirpszy nie mógłby zostać uznany za wiersz religijny.

Por. D.C. Barber Deleuze and the Naming of God. Postsecularism and the Future of Immanence, Edinburgh University Press, Edinburgh 2013 (zwłaszcza pojęcie „wiary immanentnej”); K. Justaert Theology after Deleuze, Continuum, London-New York 2012. W opinii W. Lorenca filozofia Deleuze'a „jest nowym sposobem mówienia o Bogu i jego działaniu oraz o relacji pomiędzy Bożym światem a światem doczesnym" (tegoż Foucault, Derrida i Deleuze jako reprezentanci filozofii skończoności, w: Foucault, Deleuze, Derrida, red. B. Banasiak, K.M. Jaksender, A. Kucner, Wydawnictwo Adam Marszałek, Toruń 2011, s. 354).

51 J.D. Caputo Widmowa hermeneutyka. O słabości Boga i teologii wydarzenia, przeł. A. Malinowska, J. Socko, w: Drzewo Poznania. Postsekularyzm w przekładach i komentarzach, red. P. Bogalecki, A. Mitek-Dziemba, FA-artEUniwersytet Śląski, Katowice 2012, s. 131, 126. Tamże, s. 123.

G. Deleuze Logika sensu, s. 246. 
teologiczno-religijnym jako o widmie. Strategia Wirpszy byłaby tu tyleż przewrotna, co radykalna: odmawiając swoim późnonowoczesnym „rytmom duchowym" łaski „okolicznikowości”, w jedyny możliwy sposób wyprzedza on sekularną prognozę stopniowego wymierania i nieuniknionej śmierci języka religii - zadaje mu śmierć. Dzięki temu jednak ocala go w postaci widma. Darując językowi religii śmierć, obdarza go nowym, pośmiertnym życiem, dzięki czemu, jako widmo, może on nawiedzać dyskursy i rzeczywistości, w których żyjemy. Ów stan języka religijnego, nie całkiem umarłego, ale niezdolnego do wyrażenia aktualnego doświadczenia, został dobrze opisany we fragmencie eseju Agambena poświęconym Wenecji:

Pamiętajmy jednak, że języka nigdy nie powinniśmy nazywać martwym, bo czyta się go jeszcze i w jakiejś mierze posługuje się nim w mowie; jest tylko niemożliwe - lub prawie niemożliwe - wystąpić w języku martwym jako podmiot, jako ten, który mówi „ja”. Język martwy jest, całkiem jak Wenecja, językiem widmowym, którym nie możemy właściwie mówić, lecz który na swój sposób drży, daje znaki i szepce, który możemy zrozumieć i odcyfrować - choć nie bez trudu, bez pomocy słownika. Do kogo język martwy przemawia? Do kogo zwraca się widmo języka? Z pewnością nie do nas, a także nie do tych, do których ten język przemawiał niegdyś i których zupełnie już zapomniał. A przecież dlatego właśnie wydaje się teraz, że on sam po raz pierwszy przemówił. ${ }^{54}$

Postrzegając zastany język duchowości jako taki, którym z „pomocą słownika” wciąż jeszcze dajemy radę się posługiwać, ale w którym nie potrafimy już rozpoznać się jako „ja”, traktuje go Wirpsza w pewnym sensie jako język niczyj, niepozwalający wyznać credo żadnej religii, niegwarantujący żadnej wyznaniowej tożsamości, nieodpowiadający na żadne sformalizowane objawienie. A jednak, właśnie z uwagi na swoją widmowość, język ów wydaje się wreszcie przemawiać bezpośrednio do nas, otwierając przestrzeń nadziei na mesjańską realizację obietnicy zbawienia. Agamben kończy swój esej w ostrożny, lecz wymowny, sposób: „ten tylko, kto potrafi się z duchami oswoić i zyskać ich zaufanie, odczytać i zapamiętać ubogie słowa i kamienie, pewnego dnia może będzie w stanie wkroczyć na drogę, na której historia - samo życie - wywiąże się nagle ze swoich obietnic"55. Póki co jednak żyjemy życiem, 
w którym przyświadczenie wiary objawia się nam prawie wyłącznie w bezokoliczniku - jako „wierzyć” (credere), będące czymś w rodzaju nie-mojego, uniwersalnego spektrum wiary - prawie nigdy zaś w (pierwszo)osobowej, angażującej i egzystencjalnie zobowiązującej formie „wierzę” (credo). Wyrosła z takiego rozpoznania poezja, poruszająca - niejako wbrew niemu - tematykę teologiczno-religijną, będzie poezją pozbawioną pierwszej osoby, poezją bez okoliczności. Tego typu „bezludna" ${ }^{56}$ postać charakterystyczna jest dla wielu pozornie „religijnych” utworów Wirpszy - takich jak choćby Rabunek i sen, Powrót w zamęcie, Karnawat, Nie ma raju, Spis ludności czy Konfesja. Niejako założona przez ich problematykę „doświadczeniowa” kreacja podmiotu jest w nich uporczywie nieobecna i chociaż wciąż mamy ją przed oczyma niczym powidok, niemożliwy wydaje się w nich - jak ujmuje to Anna Kałuża - „powrót do języka lirycznie miękkiego, opatrzonego gramatycznym «ja»"57.

\section{Nieudany egzorcyzm (i dalekie światła)}

A jednak w Zgryzocie „ja” zostanie w pewnej chwili wywołane - i prawie natychmiast rozpuszczone w „sinej chmurze” kolejnego widma. Prześledźmy na koniec ów proces, z konieczności ograniczając się przy tym do wyliczenia tych fragmentów tekstu, które z pewnością domagają się dłuższego komentarza. Już jego inicjalna strofa jawi się jako przenikliwy opis przebiegu widmowej deregulacji języka, którą Wirpsza podkreśla nie tylko ewokującymi wahanie parentezami czy niezgodnością toku składniowego i wersowego, ale także wykorzystaniem warstwy brzmieniowej („mowie stękania i jęczenia” poświęcona będzie strofa kolejna). Uciekając się do przywołującego porządek naukowego wywodu paralelizmu (postawienie problemu - rozumowanie - wnioski), konsekwentnie zastępować będzie Wirpsza spodziewany ruch myśli onomatopejami, odnoszonymi do domeny pisma. Tuż po wyłonieniu się "trójki widm w bezokoliczniku” usłyszymy zatem „szelest zapisu papierów traktatów”, następnie „dudnienie oprawnych ksiąg rozpraw historycznych”, w końcu zaś „syk służalczego krasomówstwa”. Ten ostatni leksem

56 "Bezludyzm”, mający oznaczać postawę skrajnie ludycznej „«anty-egzystencjalności»”, zarzucał programowi Wirpszy ). Kwiatkowski (Wtej grze można wiele przegrać, "Życie Literackie” 1966 nr 33, s. 6).

57 A. Kałuża Witold Wirpsza: anielska maszyna, w: tejże Wola odróżnienia. O modernistycznej poezji Jarosława Marka Rymkiewicza, Julii Hartwig, Witolda Wirpszy i Krystyny Miłobędzkiej, Universitas, Kraków 2008, s. 184. 
wyprowadza nas, co prawda, z porządku pisma (traktaty retoryczne) w stronę mowy (nieprzypadkowo wybiera Wirpsza ten synonim retoryki, który czytelniej odsyła do porządku głosu), lecz niejako zatrzymuje się w pół kroku („krasomówstwo” to jednak nie akt, a ars). Demonów nie uda się już bowiem przepędzić - „odpowiedzią” na następne „pytanie” może być tylko pojawienie się kolejnego widma, tym razem już nie tylko językowego (choć najpierw jest ono „zgmatwane"), ale też zadziwiająco materialnego (pochylenie, dłonie, siność, pot), doświadczającego przemocy (rzemień), lecz nade wszystko „zwierzęcego" (zwierzęcość to niezwykle ważny temat Wirpszy ${ }^{58}$, zaś jego realizację w tym akurat tekście należałoby prześledzić przede wszystkim w odniesieniu do filozofii głosu $\left.{ }^{59}\right)$. Rzecz jasna jednak, i to widmo „zrobione jest ze znaków", te zaś - korespondując z podejmowanym w tekście tematem wiary - wydają się odsyłać do znanych perykop biblijnych (Chrystusowe pisanie na piasku, Piłatowe umywanie rąk, Piotrowa wizja zstępującej z nieba chmury zwierząt uznawanych za nieczyste). To tutaj, w konfrontacji z opisanym widmem, jedyny raz w wierszu, do głosu dochodzi "ja”: nie przez przypadek też momentem tym - momentem przejścia od pisma do mowy, od bezokolicznika do pierwszej osoby - okazuje się krzyk egzorcyzmu („Odejdź ode mnie, widmo"). Widmo języka, stale utrzymujące nas w swojej władzy, nie przestanie jednak zarażać go „bezokolicznikowością”. Egzorcyzm nie mógł się udać - oto wraz z nieuchronnym powrotem do uogólnienia („Wszystko, co przenosi, jęczy albo stęka”, „Każdy, kto wierzy, niech się pozbywa”) pojawi się spodziewana „mnogość widm”, w tym zwielokrotniona wersja „widma zgmatwanego" w postaci „widm ciężkich zwierząt”, które - zgodnie z bliskim poecie posthumanistycznym rozpoznaniem - okazują się mieć „ludzkie dłonie". Wszystkie one stanowią zapowiedź nadejścia najważniejszego z nich: „sumienia: wielkiego widma zgryzoty”. Zważywszy na otwierającą wiersz paronomastyczną sugestię pokrewieństwa ciągu „wierzyć, wiedzieć, widzieć”,

58 Pojawia się on również w innych wierszach tomu, zwłaszcza we Śnie ze zwierzętami, w kontekście zabijania zwierząt podejmującym temat „ofiary powszechnej, / dla zbawienia" (CP 72-73), a także w przepowiadającym ponowne zainteresowanie się religią Powrocie w zamęcie z konsekwentnie rozwijającą animalną metaforykę puentą: "Ale ten powrót będzie jak stworzenie świata. / Dzirytem wielorybim poszarpana skóra / Zamulonego bawołu zakrwawi się na żółto; / Żółć i ocet pociekną spod siódmego żebra" (CP 159).

Zwierzę, jak w odniesieniu do Agambena pisze Momro, „umiera [...] nie w języku, lecz wydając z siebie organiczne, ale bezsensowne dźwięki; zostaje podporządkowane samej zasadzie śmierci" (J. Momro Widmontologie nowoczesności. Genezy, Wydawnictwo IBL PAN, Warszawa 2014, S. 522). 
dziwić może, że teraz, u jego końca, „sumienie” zostało przez Wirpszę skrupulatnie oddzielone od "sumienności" - niezgodnie z etymologią i inaczej niż np. w eseju Józefa Tischnera, zdaniem którego Norwidowska „«sumienność słowa» znaczy nie tylko po prostu trafność. Znaczy wydobywanie treści słów z treści sumienia. Osadzanie ich na sumieniu" ${ }^{60}$. W postsekularnej poezji Wirpszy konieczne jest, jak się okazuje, ich apellejskie rozdzielenie, tworzące wąski prześwit mesjańskiego światła: podczas gdy na „splotach sumienności" - stanowiących czytelną peryfrazę wypełnionej cierpieniem codziennej krzątaniny prowadzącej do nieuchronnej śmierci - zasadza się "mnogość" towarzyszących nam widm (moment spętanego zwierzęcia), to po trzykroć „wielkiemu” abstrakcyjnemu sumieniu (w stosunku do sumienności pozostającej w takim stosunku jak bezokolicznik do osobowych form czasownika) udaje się jakimś cudem przeistoczyć zgryzotę egzystencji w widmo („wielkie widmo zgryzoty”), a następnie w światło („dalekie światła zgryzoty"). Na skutek tej spektralnej transformacji cierpienie, co prawda, nie zanika (kolejną peryfrazą sumienia okazuje się wszakże „wielki rzemień zgryzoty”), lecz jednak powróz w jakiś sposób zamienia się w przewóz („wielki przewóz zgryzoty"), ten zaś koniec końców może nas przetransportować ku światłu. Nie należy jednak przypisywać Wirpszy naiwnej i przesadnie optymistycznej afirmacji cierpienia (per aspera ad astra). Jego „sumienie" pozostaje odczarowane, jego etyka - retoryczna, zaś „dalekie światła” gwiazd na nieboskłonie jego poezji, niczym w wielkim mieście Baudelaire’a, są ledwo widoczne: nie udzielają one iluminacji, lecz - jak pisze Jakub Momro - „powodują, że rzeczywistość jest dostępna jedynie w widmowej inwersji, w niemym powidoku tego, co jeszcze nie umarło ostatecznie, ale już pozostało uśmiercone w anihilującym wszelką osobowość procesie modernizacji"61. Stać się godnym wydarzenia nawiedzającego nas w takiej postaci, bez daty, bez imienia, bez okoliczności - oto stawka postsekularnej poezji Witolda Wirpszy $^{62}$.

60 J. Tischner O sumieniu romantycznym słów kilka, w: C. Norwid Sumienie słowa. Wybór myśli z listów i rozpraw, Ossolineum, Wrocław 2004, s. 11.

61 J. Momro Widmontologie nowoczesności..., s. 355.

62 Już "w dalekim świetle" analizowanego wiersza jasne staje się, że to o tę stawkę zagra Wirpsza va banque w swoich późniejszych tekstach o tematyce teologicznej, zwłaszcza w Liturgii, której pewne fragmenty (szczególnie te poświęcone sumieniu oraz te, w których mozolnie wypracowuje on nowe sposoby artykułowania wiary w pierwszej osobie) dają się odczytywać jako ponowne przemyślenie intuicji Zgryzoty i dalekiego światła. 


\section{Abstract}

\section{Piotr Bogalecki}

UNIVERSITY OF SILESIA (KATOWICE)

'Three Spectres in the Infinitive': Witold Wirpsza's Spectral Conjugations

This article presents an interpretation of Witold Wirpsza's poem 'Zgryzota i dalekie światło' [Distress and a Distant Light]. Bogalecki begins with an analysis of the poem's formulas and procedures in a Deleuzian context. His goal is twofold: first, to deduce Wirpsza's understanding of the theme of the spectre, which only becomes meaningful through Jacques Derrida's hauntology and the works of Giorgio Agamben and John D. Caputo. The second goal is to indicate a direction for a post-secular reinterpretation of Wirpsza's work. His return to the theological or religious tradition can be understood as a deconstruction of the traditional form of religious and metaphysical poetry. The effect turns out to be an affirmative recognition of the language of religion as a spectre that incessantly 'haunts' modern, seemingly secularized discourses.

\section{Keywords}

Witold Wirpsza, Zgryzota i dalekie światło [Distress and a Distant Light], linguistic poetry, post-secularism, hauntology, spectre 